\title{
Revealing the potential of fraud in the financial management of village-owned enterprise
}

\author{
Aprina Nugrahesthy Sulistya Hapsari ${ }^{1}$, Intiyas Utami ${ }^{2}$, Yohanes Yakobus Werang Kean ${ }^{3}$ \\ ${ }^{1,2}$ Accounting Department, Universitas Kristen Satya Wacana, Salatiga, Indonesia \\ ${ }^{3}$ History Education Department, Universitas Flores, Flores, Indonesia \\ ${ }^{*}$ Corresponding author email: aprina@uksw.edu
}

A R T I C L E I N F O

Article history:

Available online

Keywords:

Village-Owned Enterprise

(BUMDes), Fraud, Financial

Management

DOI:

https://doi.org/10.20885/jaai.vol25.i

ss1.art10

\section{A B S T R A C T}

This research is a qualitative-descriptive study conducted to identify fraud that occurs in the financial management of BUMDes (Village-Owned Enterprises). BUMDes is a business entity established through village capital inclusion which aims to manage existing assets, services, and businesses for village income contribution. In connection with this capital management, villages are required to be fully responsible for managing their capital in a transparent and accountable manner. The object of this research is BUMDEs (Village-Owned Enterprise) $\mathrm{X}$ in Wologai Tengah Village of Ende, Flores, where data collection was obtained through in-depth interviews with sources and documentation of documents that can support the results of this research. The results show that BUMDes X in Wologai Tengah Village of Ende, Flores is still vulnerable to the potential risk of fraud. This is because some parties still feel that their interests are more important than that of others. However, BUMDes X still promotes a culture of deliberation that involves the community in making decisions.

\section{Introduction}

Indonesia as a developing country is currently still focusing on infrastructure development and human resources development. The Indonesian Central Statistics Agency (Badan Pusat Statistik, 2020) noted that the human development index (HDI) in 2019 increased by 0.74 percent compared to 2018. The increase in HDI in 2019 reached 71.92. Infrastructure and human resources development are one of the government's efforts out of nine national goals designed to increase economic growth and the welfare of its people. There is still a discrepancy in economic growth between cities and villages in Indonesia. Therefore, the current development starts from suburbs and villages.

Villages play a role as the government's frontline partner that can reach the government's main target for welfare, which in this case, the welfare of communities (Ramadana et al., 2013). Villages also have the responsibility of carrying out physical development and human resources development as an effort to improve the quality of life and welfare of rural communities (Anggraeni, 2016). In this regard, the government subsequently enacted Law No. 6 of 2014 concerning villages (2014) which provides a new paradigm that welfare and high economic growth do not always exist or start from urban areas but can be started from villages. A village as the smallest unit of a nation has the authority to regulate the interests and welfare of its people.

Based on the Law on villages, community welfare and economic growth in villages can be achieved through village entrepreneurship activities that are accommodated in Village-Owned Enterprises (BUMDes) (Prabowo, 2014). Entrepreneurship in the village can encourage the growth of the village economy so that entrepreneurship becomes a strategy in the development and growth of community welfare (Ansari et al., 2013). BUMDes itself is the enterprise established by the village government which its capital is owned and managed by the village government and village people. BUMDes is a business entity that all or most of the capital owned by the village through direct investment coming from separated village assets to manage assets, services, and other businesses that are expected to contribute to the village income.

Based on the responsibilities assumed by BUMDes in managing its capital, the capital management of BUMDes must be carried out in a transparent and accountable manner. However, the existing phenomenon still shows that BUMDes is not yet free from the shadow of fraudulent practices. The existing evidence shows that several cases of corruption related to the management of BUMDes funds have also occurred in several regions, such as the corruption case of BUMDes funds committed by the Head of Tanjung Raman Village of Bengkulu Province which caused state losses of Rp 120 million (Garuda Citizen, 2020). A similar case regarding the abuse of village fund management also occurred which was done by the former Village Head of Sumbersalak of Jember Regency. The suspect used the fund for personal needs which caused state losses of Rp 600 million (Kompas.com, 2020). The misuse of BUMDes fund management also occurred in BUMDes Sumberjo of Lamongan Regency, East Java Province, which 
implicated the former village secretary and the Ekbang Head of Pucuk District. The abuse was in the form of corruption committed by the two suspects with total state losses of Rp 786.513 million (Faktualnews.cod, 2020). Several studies related to fraud in the financial management of BUMDes are still interesting topics to study. Indrayani et al. (2019) in their research, conducted a test on the influence of supervisor competence, work experience, and organizational commitment on fraud detection in BUMDes in Buleleng Regency which showed that these three variables significantly affected fraud detection in BUMDes in Buleleng Regency. Furthermore, Yanti and Musmini (2020) used a technological approach in the form of an accounting information system as an effort to increase the transparency of BUMDes financial management.

Based on existing phenomena and researches, this research needs to be done to identify potential frauds that may occur in the financial management of BUMDes X in Wologai Tengah Village of Detusoko District, Ende Regency. This research was conducted to map the potential fraud that could occur in BUMDes X from the current operational activities. Disclosure of potential fraud needs to be done on BUMDes that was only formed in 2019 so that they can formulate policies that minimize the risks of fraud in the future. This research is expected to be useful for $B U M D e s \mathrm{X}$, namely as a form of evaluation and as a reference in developing existing regulations to minimize the potential for fraud in BUMDes management. Besides, this research is expected to be useful for related agencies, namely as a guide in developing BUMDes optimally, so that the main goal in the welfare of rural communities can be achieved. For academics, this research is expected to describe the forms of fraud that potentially arise in the management of BUMDes, which in the end this empirical evidence can be used as additional insights in further research.

\section{Literature Review}

\section{Fraud}

Speaking about the potential for fraud that can be found in BUMDes management, it cannot be separated from the concept of fraud itself. Until now, fraud is still a very serious problem for organizations and stakeholders associated with the organizations (Trompeter et al., 2013). To date, there is still no single agreed definition to be used in explaining fraud itself. Fraud is a fraudulent scheme carried out on purpose that causes losses to certain parties and benefits the perpetrators of the fraud (Ristianingsih, 2017). The definition of fraud is also explained by KPMG public accounting firm as an action that is deliberately planned and carried out to seize the properties or rights of others directly or indirectly (Sow et al., 2018). Deloitte (2012) defines fraud as a misrepresentation that carried out deliberately from the existing facts made by one person to another person to persuade others to commit fraud. Furthermore, OJK (Otoritas Jasa Kuangan/Financial Services Authority) in 2019 as the financial services sector supervisory agency defines fraud as a deliberate action to deceive or manipulate certain parties to cause the parties to suffer losses. However, Tuanakotta (2010) states that the steps that can be taken by organizations are only to minimize fraud because of the complexity and various factors driving such fraud to occur.

Research conducted by (Cressey, 1953) explained that three factors underlying an individual in committing fraud, namely pressure, opportunity, and rationalization of fraudulent behavior. Pressure as the first factor that drives an individual to commit fraud will lead to more unethical behaviors. Every fraudster faces some pressure to engage in unethical behaviors. Romney and Steinbart (2012) explain that two factors encouraging an individual to commit fraud, namely pressure as an employee and pressure of financial statement. Salman (2005) explains that lifestyle demands, financial inadequacy, gambling, attempts to trick the system, and forms of job dissatisfaction prompt an individual to commit fraud.

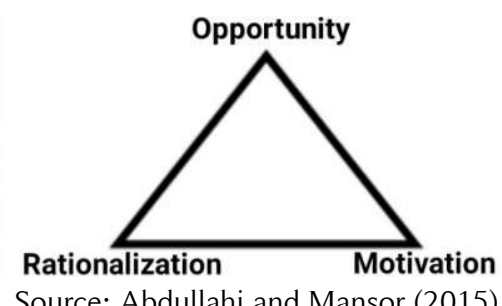

Figure 1. Fraud Triangle

Over time, the concept of triangle fraud has been expanded. Wolfe and Hermanson (2004) introduced a fraud diamond concept by adding a capability factor to the fraud concept. Even though the perceived pressure goes hand in hand with opportunity and rationalization, fraud can occur with the presence of a fourth factor, namely capability (Wolfe \& Hermanson, 2004). The new framework introduced by Wolfe and Hermanson can help managers and practitioners to find solutions to prevent or minimize frauds (Ruankaew, 2016). 


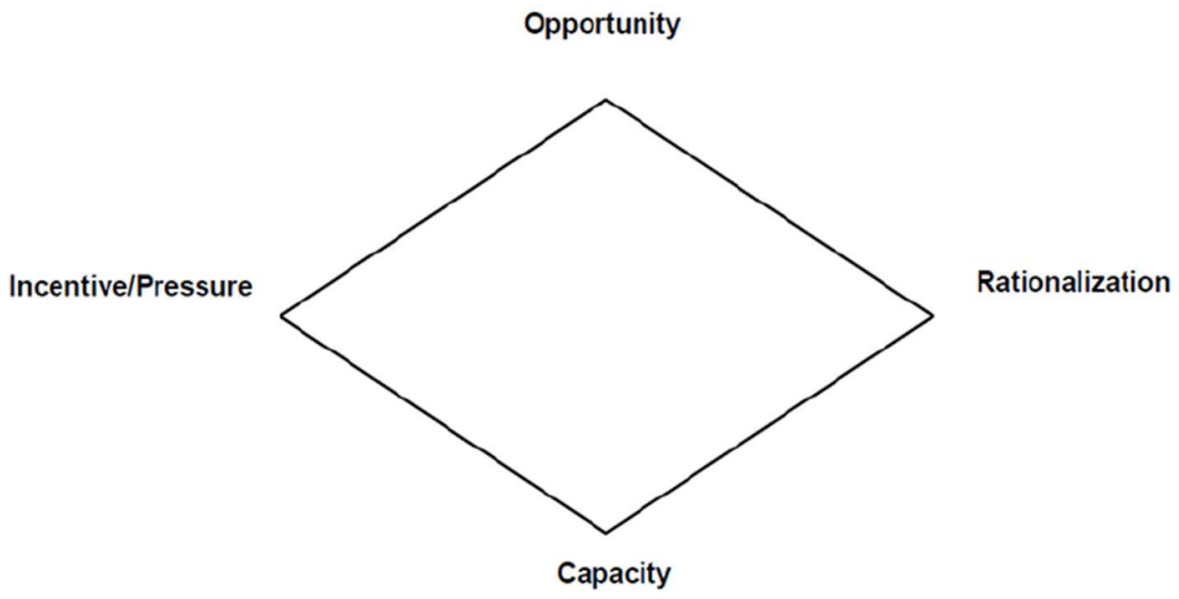

Source: Wolfe and Hermanson (2004)

Figure 2. Diamond Fraud

Besides the fraud diamond concept, a fraud concept was also developed and refined by Crowe Howarth. In the new framework, the fraud pentagon adds arrogance to the four existing factors in the diamond fraud concept as a factor that encourages an individual to commit fraud (Crowe Holrath, 2011). Bawekes et al. (2018) revealed that a high level of arrogance can encourage an individual to commit fraud. Arrogance is a trait in which a person positions himself to be more capable of committing fraud (Faradiza, 2019). The emergence of this trait is based on the dominance of selfishness which in turn encourages the individual to become more arrogant. Aprilia (2017) argued that arrogance can trigger a belief that an individual is immune to the law when the fraud is committed.

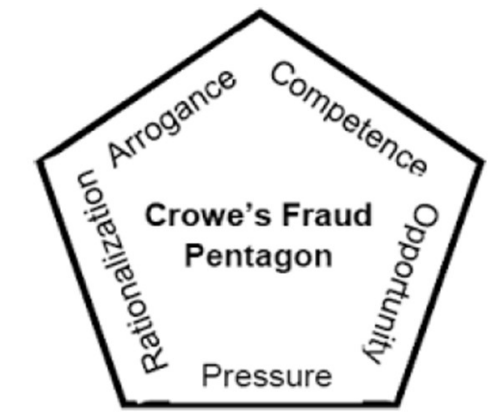

Source: Apriliana and Agustina (2017)

Figure 3. Pentagon Fraud

\section{BUMDes Management}

BUMDes as a business entity established by a group of village people to make the community to be prosperous is a complex and heterogeneous business entity. The complexity of BUMDes raises the need for information related to planning and control in BUMDes management for stakeholders. BUMDes is increasingly required to be able to meet this information need, both for internal and external parties. Therefore, good organizational management is needed by BUMDes to provide information and a good image for stakeholders.

In his research Ridlwan (2014) identified that BUMDes management must be based on 6 (six) BUMDes management principles. First, all elements of BUMDes are required to be able to work together to develop BUMDes (cooperative). Second, all BUMDes elements must voluntarily play a role actively in advancing BUMDes (participative). Third, all existing BUMDes elements have the same position and treatment (emancipative). Fourth, all BUMDes business activities must be accountable to the public in an open manner (transparent). Fifth, BUMDes must be accountable for all of its business activities, both technically and administratively (accountable). Sixth, BUMDes are required to be able to run and develop their business (sustainable). In achieving the principles of BUMDes management, it is necessary to be supported by good financial management as well. BUMDes finances as part of the village must be managed based on the principles of transparency, accountability, and participation, and carried out in an orderly and disciplined manner (Home Ministry Decree No. 20, 2018). Therefore, good management organization and finances of BUMDes can serve as a preventive measure against potential frauds in the implementation of BUMDes business activities. 


\section{Research Method}

\section{Types of Research and Data Collection Techniques}

This research was conducted using a qualitative descriptive approach that describes objects of this research naturally by investigating the phenomena and existing social problems. Indayani (2020) in her research also states that qualitative research is usually carried out to examine things that happen in the environment and try to interpret a fact, based on people's judgments about it. This research used BUMDes X of Wologai Tengah Village, Ende, Flores as the object of research. The data in this research were obtained through the activity of a group discussion forum (GDF) with all related sources in this research. The resource persons referred to in this research include the traditional leaders of Wologai Tengah Village (Mosalaki), BUMDes Management, Head of Village Community Empowerment Service of Ende District, Head of Kelimutu National Park Office, and representatives of the existing community. To add to existing data, secondary data collection was also carried out by reviewing the documents related to this research.

\section{Data Analysis Technique}

The data analysis technique in this qualitative study uses three lines of analysis. As explained by Hapsari and Seta (2019) in their research, the first data analysis technique performed was data reduction by interviewing sources in this research. The data reduction was done to filter general and complex raw data into simpler data so that data can be easily understood and a clearer picture can be obtained. To ensure the originality of the data that has been obtained, the validity test was then carried out, based on the results of data reduction. Data validity testing was carried out by comparing the data with viewpoints of different sources by using the data triangulation technique. Finally, the verified data was presented in the form of narrative text which completely provided a clear picture of the content to be conveyed in this research. This complete picture allows a conclusion to be drawn which then underlies an action to be taken.

\section{Results and Discussion}

\section{Description of Research Objects}

Wologai Tengah Village is one of the destinations that should not be missed by tourists when visiting Flores. Wologai traditional village is located at an altitude of 1,045 meters above sea level and has become one of the remaining traditional villages in Flores and has been there for approximately 800 years. Wologai Village is located 37 kilometers east of Ende City of Detusoko District, which is currently inhabited by 882 people. Wologai traditional village is known for its strong local wisdom. The Wologai traditional village community is one of 24 indigenous Lio tribal communities living around the Kelimutu National Park with their strong and unique ancestral customs. Currently, Wologai Tengah Village is in the process of establishing a Village-Owned Enterprise (BUMDes) called BUMDes X. The establishment of this BUMDes is based on the culture and tourism potentials of the Wologai Tengah Village. Several types of business units used as objects in BUMDes $X$ are the uniqueness of ancestral heritage of traditional houses, the Boelanbong camping ground, and the sale of typical coffee from Ende.

\section{Potential for Fraud in BUMDes Financial Management}

In the process of its formation, BUMDes cannot be separated from various potential problems, one of them is the potential for fraud that can be carried out from internal and external parties. BUMDes was founded for the interests of many parties in the village with one goal, namely the welfare of the village community. Every dream and hope of the village community was put together through deliberation and made into RPJMDes (Village Mid-Term Development Plan).

Several important components can become targets for potential fraud. From the planning stage that starts from idea gathering to budgeting, the potential for fraud will always exist. One of them is related to the potential for fraud in financial management starting from the time of making the budget, which is the basis of every implementation. BUMDes X has several potentials that can be developed and sold, namely the Boelanbong camping ground, traditional villages, and coffee. These three things can go on and run when there is budgeting to meet the operational and non-operational needs of BUMDes. However, sometimes the budgeting process can be misused and lead to potential fraud, this is because each object is important.

The potential for fraud that occurs can be in the form of cash theft caused by inappropriate budget planning. All objects submit concerning the high amount of budget, not for implementation, but the benefit of each party. The strong custom in Wologai village also sometimes causes a feeling of "losing vote" for the other parties. As said by one of the Boelanbong managers:

"In terms of human resources, we still need a lot of equipment. Besides, we have everything here

but the village will always close its eyes when it comes to money. Money is always advancing, 
even though we want this object to advance first, not for the interest of each party who wants progress".

Also, many parties who knew about the budget owned by BUMDes ultimately caused several of those parties to want a share of the budget, even though the budget was not made for personal interest but the sustainability of BUMDes. This issue was reiterated by the Head of the Kelimutu National Park:

"Indeed, obstacles do exist when Boelanbong and traditional houses have been prospected to become tourist objects, there are some people are angry and feel that they do not receive any shares, eventually, it causes resentment among them and hinders the development."

This illustrates that the potential for fraud often occurs when it comes to money. There are still many people who only want to satisfy their desire without caring about their real needs.

The potential for fraud can take place during implementation, especially when it comes to financial management. For example, fraud in form of cash theft which it does not only occur during the budgeting process but also happens when the division of tasks in financial management has not been properly mapped out. This is as explained by one of the village administrators:

"For the tourist objects, we do not have tariffs and no one has been assigned to manage funds and there is no evidence of management such as tickets. We only rely on our trust."

The basis of trust in management, especially in finance, can lead to potential fraud that can be done by anyone at any time. The bookkeeping process is also still carried out unprofessionally due to BUMDes administrators' limited knowledge, which on average they only graduated from primary and secondary schools. This issue is stated by the elected BUMDes Director:

"We still don't have good bookkeeping knowledge. In the past, I was only a village financial manager which I did the recording by myself. Therefore, I hope that there will be a lot of learning and provisioning for us later."

Bookkeeping or administration that is not carried out properly and regularly can lead to potential fraud. For example, the recording of cash that is not done by the standard procedure will prompt a theft of cash affected by an improper accounting process. Bookkeeping that is not done properly can ultimately have impacts on reporting and accountability processes. In the reporting stage, a report which is based on unreal events may occur which eventually place BUMDes officers in a disadvantaged position. Especially in the accountability stage where it reaches the accountability of the head of regency, inappropriate reporting will create suspicion that will ultimately impact the process of BUMDes performance itself.

Furthermore, the potential for fraud can also occur in the process of conveying community aspirations in Musrenbangdes (Village Development Planning Deliberation). Normally, the implementation of Musrenbangdes is carried out by involving all citizens who will present all their aspirations in this event. Unfortunately, the implementation of the Musrenbangdes always invites some parties without involving members of the community whose aspirations actually really need to be heard. But in the implementation of BUMDes X all parties are invited to carry out deliberations to reach an agreement, as stated by one of the community leaders as follows:

"In every decision making, we are always invited to express our dreams and hopes for the development of the village and BUMDes."

However, there are still problems coming from other parties outside the community. For instance, those who are invited to the deliberation do not wish to attend the event but will only attend when they feel that they are in a disadvantaged position. This condition is stated by one of the community leaders:

"Many parties refuse to discuss this concern, but when it comes to their interests they usually will attend and insist on defending any concerns related to their interests."

The existence of a potential for fraud is real and undeniable. We are sometimes unaware of financial cracks that can eventually open the opportunity for fraud to occur. However, through a commitment to growth, the potential for fraud can be suppressed for the smooth development and implementation of BUMDes.

\section{Discussion}

The development of BUMDes in Wologai Tengah cannot be separated from various ideas and conflicts in it. BUMDes X was formed based on an idea that had been accommodated from the dreams and hopes of the village community for the development and improvement of the welfare of Wologai Tengah Village people. Nonetheless, in the implementation, BUMDes X is still encountering obstacles that can hinder its development, one of which is the potential for fraud. 
Although every planning and implementation always emphasizes the principle of honesty, some parties cannot implement this principle. Instead, these parties choose to satisfy their own needs and interests, especially when it comes to financial matters. Some parties choose to turn a blind eye to finance matters even though this includes frauds. It clears that money has become a sensitive subject and has a great potential to be the source of fraud. This is due to several parties who consider that they own the greatest interest in it.

On the other hand, the potential for fraud from the other side, such as corruption and misuse of a financial statement is not very prominent in BUMDes X. BUMDes X always involves the village community in every decision making and they are invited to think and express their ideas to create a sense of responsibility for all ideas that they have given. Although this positive atmosphere still occurs, obstacles still appear coming from the traditional leaders, i.e. some Mosalaki who refuse to attend the Musrenbangdes meeting. Some people choose not to attend the meeting because they consider that the meeting cannot accommodate their interests. But when problems are threatening their interests, they will attend and raise their objections.

The potential for fraud is real in the village especially related to financial management such as in the planning, implementation, administration, reporting, and accountability processes. The planning and administration stages are prone to fraud which this condition will ultimately impact the reporting and accountability processes. The government should realize that when the five stages are not carried out properly or frauds committed by individuals, it can have long impacts on the implementation of BUMDes itself.

These factors illustrate that the potential for fraud can occur in financial management. Some people want to get their shares without proper planning. Cash theft usually is not carried out directly because it is done, for example, by making budget markups for the self-interest of the perpetrator and inappropriate financial recordings that in turn, it impacts financial reporting and accountability (Utomo, 2018). Potential for fraud will still exist amid positive things that have taken place in BUMDes X, especially when this business entity consists of several parties.

\section{Conclusion}

The potential for fraud is inevitable from the activities of development or planning. This is true for BUMDes $\mathrm{X}$ which is in the process of being developed. Many things have been planned which include budget planning, which turns out to be prone to frauds. Some people consider that their interests are more important than that of others which prompts the occurrence of cash thefts by making budget markups for the self-interest of those people, not for the sake of the development of BUMDes. However, not all potentials for fraud occur in the development process of BUMDes X because the strong culture of Musrenbangdes (deliberation) still exists among the community of the village which is carried out by involving the community members to reach a decision.

The COVID-19 pandemic has limited this research and implementation of FGDs. Various COVID-19 protocols and restrictions have caused the implementation of offline FGDs to be postponed and preparations of FGD to be held online. Also, this research is constrained by less educated human resources related to BUMDes and constrained by narrow-minded perspectives of some people about the function of BUMDes and about ways to develop BUMDes.

The implementation of activities of this research in the Traditional Village of Wologai Tengah has been going well. But in the next research, it is hoped that provisions can be given that include brief education concerning BUMDes and knowledge about the potential for fraud and the potential risks when fraud is carried out. It is hoped that the provisions can minimize the severity of frauds.

\section{References}

Abdullahi, R., \& Mansor, N. (2015). Fraud triangle theory and fraud diamond theory. Understanding the convergent and divergent for future research. International Journal of Academic Research in Accounting, Finance and Management Sciences, 5(4), 38-45. https://doi.org/10.6007/IJARAFMS/v5-3/1823

Anggraeni, M. R. R. S. (2016). Peranan badan usaha milik desa (Bumdes) pada kesejahteraan masyarakat pedesaan studi pada Bumdes di Gunung Kidul, Yogyakarta. Modus Journal, 28(2), 155-167. https://doi.org/10.24002/modus.v28i2.848

Ansari, B., Mirdamadi, S. M., Zand, A., \& Arfaee, M. (2013). Sustainable entrepreneurship in rural areas. Research Journal of Environmental and Earth Sciences, 5(1), 26-31.

Aprilia, A. (2017). Analisis pengaruh fraud pentagon terhadap kecurangan laporan keuangan menggunakan Beneish Model pada perusahaan yang menerapkan Asean Corporate Governance Scorecard. Jurnal ASET (Akuntansi Riset), 9(1), 101. https://doi.org/10.17509/jaset.v9i1.5259

Apriliana, S., \& Agustina, L. (2017). The analysis of fraudulent financial reporting determinant through fraud pentagon approach. Jurnal Dinamika Akuntansi, 9(2), 154-165. https://doi.org/10.15294/jda.v7i1.4036 
Badan Pusat Statistik. (2020). Indeks Pembangunan Manusia (IPM) Indonesia pada tahun 2019 mencapai 71,92. Badan Pusat Statistik. https://www.bps.go.id/pressrelease/2020/02/17/1670/indeks-pembangunanmanusia--ipm--indonesia-pada-tahun-2019-mencapai-71-92.html\#: :text=Pembangunan manusia di Indonesia terus, 74 persen dibandingkan tahun 2018.

Bawekes, H. F., Simanjuntak, A. M. A., \& Daat, S. C. (2018). Pengujian teori fraud pentagon terhadap fraudulent financial reporting (studi empiris pada perusahaan yang terdaftar di Bursa Efek Indonesia tahun 20112015). Jurnal Akuntansi \& Keuangan Daerah, 13(1), 114-134.

Cressey, D. R. (1953). Other people's money: A study in the social psychology of embezzlement. Patterson Smith.

Crowe Holrath. (2011). Why the Fraud Triangle is No Longer Enough. Sarbanes Oxley. http://www.sox.com/dsp_getWebinarDetails.cfm?CID=2668

Deloitte. (2012). Managing fraud risk: being prepared. https://www2.deloitte.com/content/dam/Deloitte/in/Documents/risk/Corporate Governance/Audit Committee/in-gc-managing-the-business-risk-of-fraud-noexp.pdf

Dorminey, J. W., Fleming, A. S., Kranacher, M.-J., \& Riley, R. A. (2010). Beyond the Fraud Triangle. The CPA Journal, 807), 17-24.

Faktualnews.cod. (2020). Kejari Lamongan Tahan 2 Tersangka Korupsi DD dan Dana BUMDes Rp 786 Juta. Faktualnews.Co. https://faktualnews.co/2020/08/13/kejari-lamongan-tahan-2-tersangka-korupsi-dd-dandana-bumdes-rp-786-juta/228737/

Faradiza, S. A. (2019). Fraud pentagon dan kecurangan laporan keuangan. EkBis: Jurnal Ekonomi Dan Bisnis, 2(1), 1-22. https://doi.org/10.14421/ekbis.2018.2.1.1060

Free, C. (2015). Looking through the fraud triangle: A review and call for new directions. Meditari Accountancy Research, 23(2), 175-196. https://doi.org/10.2139/ssrn.2590952

Garuda Citizen. (2020). Korupsi Dana Bumdes, Kades Tanjung Raman Ditahan Jaksa. Garuda Citizen. https://bengkulu.garudacitizen.com/2020/06/26/korupsi-dana-bumdes-kades-tanjung-raman-ditahanjaksa/

Hapsari, A. N. S., \& Seta, D. W. (2019). Identifikasi kecurangan dan whistleblowing universitas. Jurnal Riset Akuntansi Dan Keuangan, 7(1), 131-144. https://doi.org/10.17509/jrak.v7i1.15424

Indayani, B. (2020). Calculation of depreciation fixed assets based on government accounting standards and their impact on financial statements. Point of View Research Accounting and Auditing, 1(3), 43-48. https://doi.org/10.47090/povraa.v1i3.34

Indrayani, N. K. D., Sujana, E., \& Dewi, P. E. D. M. (2019). Pengaruh kompetensi pengawas, pengalaman kerja, dan komitmen organisasi terhadap pendeteksian kecurangan pada Badan Usaha Milik Desa (BUMDES) se-kabupaten Buleleng. Jurnal IImiah Mahasiswa Akuntansi Universitas Pendidikan Ganesha, 10(2), 158169.

Kompas.com. (2020). Korupsi Dana Desa, Mantan Kades di Jember Ditetapkan sebagai Tersangka. Kompas. https://regional.kompas.com/read/2020/07/03/18530601/korupsi-dana-desa-mantan-kades-di-jemberditetapkan-sebagai-tersangka

Prabowo, T. H. E. (2014). Developing Bumdes (village-owned enterprise) for sustainable poverty alleviation model village community study in Bleberan-Gunung Kidul-Indonesia. World Applied Sciences Journal, 30, 1926. https://doi.org/10.5829/idosi.wasj.2014.30.icmrp.4

Rae, K., \& Subramaniam, N. (2008). Quality of internal control procedures. Managerial Auditing Journal, 23(2), 104-123. https://doi.org/10.1108/02686900810839820

Ramadana, C. B., Ribawanto, H., \& Suwondo, S. (2013). Keberadaan badan usaha milik desa (BUMDES) Sebagai penguatan ekonomi desa. Jurnal Administrasi Publik Mahasiswa Universitas Brawijaya, 1(6), 1068-1076.

Undang-Undang No. 6 Tahun 2014 Tentang Desa, Pub. L. No. 6, 1 (2014).

Home Ministry Decree No. 20, Pub. L. No. Home Ministry Decree No. 20, 120 (2018).

Ridlwan, Z. (2014). Urgensi Badan Usaha Milik Desa (BUMDES) dalam pembangun perekonomian desa. Fiat Justisia Jurnal Ilmu Hukum, 8(3), 424-440. https://doi.org/https://doi.org/10.25041/fiatjustisia.v8no3.314

Ristianingsih, I. (2017). Telaah konsep fraud diamond theory dalam mendeteksi perilaku fraud di perguruan tinggi. 
Seminar Nasional Ekonomi Dan Bisnis, 128-139.

Romney, M. B., \& Steinbart, P. J. (2012). Accounting Information Systems (12th ed.). Pearson Education Limited.

Ruankaew, T. (2016). Beyond the Fraud Diamond. International Journal of Business Management \& Economic Research, 7(1), 474-476.

Salman, K. (2005). Audit investigatif: Metoda efektif dalam pengungkapan kecurangan. In Makalah Seminar Nasional Auditing Forensik. PPA UGM.

Sow, A. N., Basiruddin, R., Rasid, S. Z. A., \& Husin, M. M. (2018). Understanding fraud in Malaysian SMEs. Journal of Financial Crime, 25(3), 870-881. https://doi.org/10.1108/JFC-08-2017-0077

Trompeter, G., Carpenter, T., Desai, N., Jones, K., \& Riley, R. (2013). A synthesis of fraud-related research. Auditing: A Journal of Practice and Theory, 32(1), 287-321.

Tuanakotta, T. M. (2010). Akuntansi Forensik dan Audit Investigatif(2nd ed.). Salemba Empat.

Utomo, N. F. (2018). Evaluasi pengendalian internal untuk meminimalisasi risiko terjadinya kecurangan pada siklus pendapatan dan siklus pengeluaran UD. X di Surabaya. Jurnal IImiah Mahasiswa Universitas Surabaya, $7(2), 634-648$.

Wolfe, D. T., \& Hermanson, D. R. (2004). The fraud diamond: Considering the four elements of fraud. The CPA Journal, 74(12), 38-42.

Yanti, P. M. L. K., \& Musmini, L. S. (2020). menerapkan sistem informasi akuntansi dalam meningkatkan transparansi pengelolaan keuangan Pamsimas pada Bumdes Giri Artha. Jurnal Akuntansi Profesi, 11(1), 47-58. 